\title{
How Social Factors Influence the Understanding of the Computers by Kindergarten Pupils
}

\author{
Patrali Kyriaki \\ Department of Preschool Education, University of Western Macedonia \\ kikipatr@yahoo.gr \\ Alevriadou Anastasia \\ Department of Preschool Education, University of Western Macedonia \\ alevriadou@uowm.gr \\ Petrou Mikaela \\ Department of Preschool Education, University of Western Macedonia \\ mikaelaptr@hotmail.com \\ Anastasiadou Sophia \\ Department of Preschool Education, University of Western Macedonia \\ sofan@uowm.gr \\ Kyridis Argyris
}

Department of Early Childhood Education, Aristotle University of Thessaloniki akiridis@ nured.auth.gr

Accepted: May 17, 2012 Published: June 02, 2012

Doi:10.5296/ijld.v2i3.1814 URL: http://dx.doi.org/10.5296/ijld.v2i3.1814

\begin{abstract}
The aim of the research is to explore the views of infants and preschool aged children on computers as a concept and as an element of material culture. In other words, the research seeks to identify the ideas and concepts that the children have form on the computer and its peripheral units. At the same time there has been an effort to detecting the factors that probably affect the Greek preschool aged children's formation of views and concepts on computers. The factors that have been checked are parents' education level and profession, the existence or not of a computer in kindergarten class, the sex, the place of residence and children's age. In order for the degree of infants' conceptual change to emerge, the question "does a computer remain a computer if one of its external characteristics changes" had been investigated. The phenomenon of simile or parallelism of the computer or its parts with other objects had been observed (i.e. "the screen is like a TV" or "is a TV", "the central unit and printer are machines" etc) especially on behalf of the preschool aged children. It seems that preschool aged children compared with infants, use in higher degree more essential characteristics in order to define
\end{abstract}


computer and its parts (recognition - usage - preservation of identity). In general these findings confirm the findings of international researches which highlight the important role of parents' educational level and profession in the acquisition of knowledge on new technologies by their children. In the majority of children there were evident difficulties in defining the concept of computer and also to realize what it is what it does. This difficulty was expected as the computer is an artificial object with complex functions which essentially are based on its internal characteristics. In parallel, children's notions on the computer and its parts are depended on factors as their mother's profession and educational level as well as if there is or not a PC in kindergarten. On the contrary children's sex, the place of residence, father's educational level and profession don't seem to significantly influence children. Specifically, mother's profession influences significantly children's performance. It has been found that children whose mother is a freelancer-scientist or a public servant statistically have significantly greater numbers of right answers from the children whose mother is a farmer or a worker and from those whose mother is a privet employee, a freelancer or a merchant. Mother's educational level seems to influence children's views and notions even though something worth mentioning occurs: the greater number of right answers it is given by children whose mothers are secondary education graduates. This finding might be explained by the higher expectations that these mothers have from their children. Even though they, themselves don't graduate form a higher institution, they very much want that for their children. The lowest performances have children whose mothers are elementary school graduates. It's impressive the fact that on the question related to the computers identity change or not, no differences were found among the three groups, something that needs further investigation.

Keywords: Infants, Preschool aged children, Computers, Views

\section{INTRODUCTION}

The massification of education, for which the development of the human capital theory and the theories of equal opportunities in education and equality of outcomes had a decisive role, assigned to the formal educational system important interventional potentials in the cognitive and social development of children. The institutions of socialization have expanded. Some of them, like school or the mass media have a dominant role in shaping the cognitive and social parameters of a child's development. However, the role of the environment, mainly the family, where a child lives and grows up, seems to be determinative for its development, not only for the biological but also for the cognitive and social. The child socializes in a complex environment where it constantly draws information, sometimes conflicting, which process and reproduces them. This corpus of information transforms into social knowledge through the processes of social learning.

According to Bandura's social cognitive theory (1986 \& 1989), human performance depends both on social and cognitive factors. Learning is defined as an information processing activity, where the child receives information, which initially processes, then encodes and with the expectation of the appropriate reward or success from the school or family, it uses them, anticipating future consequences and adjusting its behavior. The information's organization and interpretation is affected by many factors. Thus, the information reference and various 
other factors, such as the socio-economic and educational level, the motives etc. determine at any time what the child understands. The environmental conditions and the social influences convey information and activate emotional reactions helping the development and modification of the beliefs and children's cognitive abilities. If, for example, the conclusions that a child draws about the knowledge of PCs, are based on insufficient or incorrect information of the family or/and school environment, then it fails to evaluate all the dimensions of the subject and therefore is led to misconceptions.

Although the interest about using the computer in schools concerns mainly school children and adolescents, only in recent years the studies of the impact of new technologies in pre-school children have begun. However, the relevant international literature remains quite limited (Calvert, Rideout, Woolard, Barr, \& Strouse, 2005; Haugland, 1999; Primavera, Wiederlight \& DiGiacomo, 2001).

In the U.S. only $38 \%$ of pre-school children use a computer at school (Kominski \& Newberger, 1999). According to the Statistic Service of Australia (2000), about the application of new technologies in pre-school education, the $50 \%$ of preschool children uses a computer at school, while in Greece, after the implementation of the European program of the Information Society (Ministry of Education \& Religion, 2004), only a small percentage of the kindergartens have a computer.

We can claim that the knowledge or skills of the preschool children are mainly social, meaning that at first they are acquired outside school and are related to social representations or activities. In that regard, it is extremely interesting both as a research assumption and as a base of understanding educational policies to take into consideration the cognitive capacities and skills of infants before they join the preschool education.

According to many researchers (Elkind, 1985; Haugland, 1992), the introduction of the computer in kindergarten has many positive effects on the cognitive development of the infant. Through guided activities by the kindergartener, they learn mnemonic strategies, enrich their vocabulary, and they acquire better motion skills (Clements, 1987 \& 1998; Haugland, 1999). Infants from the age of 3-4 years are developmentally "ready" to explore the computer device.

The questions that raise concern which factors influence the knowledge of the infants regarding the recognition and use of the computer and the regional units (central unit, screen, printer, disk, etc.).

According to the international literature the following factors seems to affect the perceptions of infants about the computer:

The educational level of their parents. Researchers have found that as the family educational level increases, the children use more complex and new-fangled problem solving strategies through the computer (Becker, 2000).

The parents' occupation. The parents' occupation is indirectly connected with the family's socio-economic status. It was found that the infants whose parents were workers (lower socio-economic layers), used the computer in a small degree (Avand \& Krosnick, 2005), to practice on something that they had already learned and not to acquire new skills or new ways of problem solving (Primavera et al., 2001). 
The gender. Although several studies favour males in relation to females in terms of knowledge and the level of computer use (Koch, 1994; Nelson \& Watson, 1991; Shashaani, 1994), other studies don't note any differences between the two genders (Bhargava, Kirova-Petrova, \& McNair, 1999; Williams \& Oqletree, 1992). The supporters of the existence of differences believe that, from the early childhood, boys have more experiences with computers and are more enthusiastic. According to Derman-Sparks (1989), already from the preschool age, the gender stereotypes play a key role in the use of computer. Thus, the computer activity is considered to fit in boys' identity better than girls' (Bradshaw, Clegg \& Trayhurn, 1995), opinion that is questioned by the newest data (Calvertetal, 2005; Subramanyam, Kraut, Greenfield \& Gross, 2001).

Place of residence (comparison between rural and urban areas). According to data from the U.S. Department of Commerce (1997), preschool children that live in rural areas have less contact with the computer and know less about its use.

The conceptual change of perception about the computer during the development. As children grow up, the knowledge about the computer characteristics and the computers use is increased. This fact isn't exclusively interpreted by the accumulation of new knowledge, but it seems that the changes that occur in connection with the structuring of concepts have an essential role (for a comprehensive review Maridaki-Kassotaki, 2002; Ziori, 2005). It's a fact that it is hard for the infants to understand and categorize artificial concepts and mainly those that correlate with objects with complex features that are not immediately perceptible (Spriegler \& Keil, 1991). Such objects are the computer and the television. The children's biggest difficulty stems from their inability to realize the internal features (e.g. parts of the mechanism) of the above devices and realize that they have the most determinative role for their function. Some researchers (Medin, 1989; Smith \& Medin, 1981) allege that children focus their attention exclusively on external features (color, shape, size) and according to them they shape the equivalent concept (known as the similarity theory). On the other hand, other researchers (Gelman \& Markman 1986 \& 1987; Keil, 1987 \& 1994) believe that children take into consideration also the hidden features of objects to categorize them into natural or artificial. They ascertain that children support their answers mostly to the categorical correlations of the objects rather than the similarity correlations, it seems that in some extent they can identify the existence of other data beyond the visible characteristics that connect the members of a category. In addition, similar results are reported by Gelman \& Wellman (1991). In their study, infants were asked to answer whether the identity or usefulness of the objects change with the removal of some internal sections. At this point, children noticed that the inner inanimate and animate components of objects determine their identity and functionality. They were able to understand the importance of hidden components, both for natural and artificial objects. It appears that infants and also older children are able to define some concepts using both the similarities of the external features traits between different objects, and data referred to some hidden features. According to Vosniadou (1992), Gelman \& Markman (1987) and Keil (1989), the infants thought does not focus only on external features of the objects perceived by their senses, but it is also affected from knowledge, experiences and their initial assumptions. In the inartificial objects difficulties are observed during the identification of the significance of internal parts and features. Within frameworks the 
researchers (Keil, 1989 \& 1994; Keil \& Butterman, 1984) designed a story for every artificial concept. Infants and schoolchildren were asked to answer whether some artificial objects could change their identity if the external characteristics had been altered and took the form of other objects (e.g. conversion of a coffee machine into a bird's alimentation case). The findings showed that infants tended to support their descriptions usually on minor features of the objects. Older children supported their descriptions also on non-salient features, like internal organs and mechanisms. Keil's findings (1989) led to the conclusion that infants use different characteristic features compared to older children or even adults, in order to determine the significance of a concept. That can be interpreted if someone takes under consideration that children's first perceptions of the world are incomplete and based more on intuitive knowledge. According to Vosniadou, (1992) \& Carey, (1985), over the years, and particularly after the age of 6 , children enrich and broaden their knowledge, which leads them to accept that some traits are more important than others for the formation of a concept.

The purpose of the current study was to explore the opinions of preschool children and infants concerning the computer as a concept and as a material culture element. In other words, the study's aimed to detect the opinions and concepts that children have formed about computer and different regional units. Simultaneously, it was attempted to identify the factors that probably influence the formation of ideas and concepts about computer in Greek preschool children. The factors examined were the parent's education and occupation status, the existence of a computer in the class, as well as the gender, the age and the place of residence. In order to spot the level of conceptual change of infants, we investigated the hypothesis that a computer continues to be a computer if an external trait characteristic is altered.

\section{METHODS}

Sample

This study was conducted during the academic year 2004-2005 in Florina's and Thessaloniki's kindergartens and in villages inside the prefecture of Florina. A total of 100 children ( 53 boys, 47 girls) volunteered to participate in the present study (55 infants, 45 preschool children). Sixty-seven of them were derived from the prefecture of Florina and the 33 from the wider urban area of Thessaloniki. Specifically, the children came from the $\mathrm{C}^{\prime}$ class of the 6th kindergarten of Florina (22 children), from the $\mathrm{B}^{\prime}$ class of the 2 nd kindergarten of Florina (8 children), from the $\mathrm{A}^{\prime}$ class of the 10th kindergarten of Florina (5 children), from the $\mathrm{A}^{\prime}$ and $\mathrm{B}^{\prime}$ class of the kindergarten of Armenochori prefecture of Florina (16 children), from the 1st kindergarten of Amochori prefecture of Florina (16 children), from the $\mathrm{A}^{\prime}$ and $\mathrm{B}^{\prime}$ class of the 102th kindergarten of Thessaloniki (Depo, 18 children) and from the 5th kindergarten of Polichni in Thessaloniki (15 children). The collected data included gender, age, occupation and educational parental level and finally the presence or absence of a computer in each kindergarten.

Father's occupation was encoded into 3 categories (1.Farmer/worker, 2. private employee/freelancer-technician/ trader and 3. Freelancer/scientist/civil servant). On the other hand, mother's occupation was encoded into 4 categories 1. Farmer/worker, 2. private employee/trader, 3. Freelancer/scientist/civil servant and 4. Household chores. 
Father's and mother's education were encoded into 3 categories (1. Higher education degree, master degree and post-graduate degree, 2. Secondary education degree 3. Graduate of elementary school or non-completed school attendance).

Finally $22 \%$ of the sample had access to a computer in the kindergarten, while $78 \%$ had not. Material and procedure

In this study, 7 different photos of parts or components of the computer were used. The lineup of photos presented was specific, starting from the central unit and continued by the screen, the keyboard, the mouse, the printer, the cd and finally the disk. For each one of these photos, infants answered in two questions, the first concerning to whether they know what they see (recognition) and the second concerning to whether they know what it does (usage). Then, without the photos presence, infants answered in two additional questions. The first was designed to collect the answers related to children's opinions on what they believe the computer is

The second question was about the maintenance or not of the PC's identity related to some changes that would occur in a level of external trait characteristics (regarding to the material e.g. wood or shape e.g. round).

The selection of infants was made using random sampling, while infants with special educational needs were excluded. Each infant was individually examined with an interview. For their familiarization an introductory conversation was carried out so that they could easier report their opinions. When the question's that were based upon the 7photos answered, two additional questions were asked. Data collection (children's answers and marital status) was held during the spring semester of 2005 (over a 3-months period), in kindergartens of Florina's, and Thessaloniki's prefectures and recorded individually (see Appendix). Each child was separately examined in order to avoid the affection by others opinions.

Children's responses were recorded in a tape recorder placed in a way to avoid their distraction. After the interviews completion, the teacher was asked to provide some additional data on the marital status of the child (occupation and education level of parents), as well as the presence or not of a personal computer in the classroom.

\section{Rating}

The 7 questions that were related to the identification of the computer's parts through the photos, the 7 questions concerning the knowledge of the use/operation of the above sections through photos as well as question $\mathrm{C}$ (what a PC is?) were graded based on a scale 1-3 (1 point: wrong answer, 2 points: incomplete response and 3points: complete-correct answer). Finally, question D (if the PC's external appearance was differed would it still be a PC?) "yes" was rated with 1 point and "no" with 0 points.

\section{RESULTS}

Variables

The questionnaire used was composed by 24 statements. Eight were related to demographic data of the subjects. 
More specifically, they were related to gender, age, place of the child's residence and the father and mother's educational/occupation level. Finally, the variable that referred to the existence of a PC in the kindergarten was used.

The remaining 16 variables related to the children's opinions about PC. Particularly, the 7 initial questions related to components of the computer (central unit, monitor, keyboard, mouse, printer, cd, floppy disk) were evaluated based on a scale of 1-3. After that a new complex variable-factor called recognition was created (Frecognition) from the total scores of the 7 questions. Similarly, the 7 initial questions related to what each part of the computer does, namely the usage of any of the computer components were evaluated based on a scale of 1-3 and afterwards a new complex variable was created- named usage factor (Fusage) from the total score of the 7 questions. Additionally, two other questions-factors were used, the first concerning what a computer is (Fwhat a computer is) and the second, if the PC's external appearance was differed, would it still be a PC (Fcontinue to be a PC).

To note whether the subject's opinions vary by demographic variables, methods of Multivariate Analysis of Variance were used.

\section{Hypothesis Testing}

For hypothesis testing Multivariate Analysis of Variance was used (MANOVA-Multivariate Analysis of Variance), (Hair et al.,1995; Sharma, 1996) followed by Univariate Analysis of Variance (ANOVA-Analysis of Variance), under the general linear model (Kirk1995; Mendenhall \& Sincich 1996; Kuehl 2000). For multiple comparisons of means, Tukey HSD method was applied, due to the fact that we had the consistency of the corresponding event dispersions (Klockars \& Sax, 1986; Toothaker, 1993). Analyses were performed using the statistical package SPSS (Kinnear \& Gray 1995; Babbie \& Halley 1998; Bryman \& Cramer 1999; Coakes \& Steed, 1999) enriched with the subsystem Exact Tests (Mehta \& Patel, 1996).

Differences between the two genders in terms of the computer's recognition and usage and what the computer is and finally if the computer's external appearance was different would it still be a computer.

Analysis showed that there was no statistically significant difference on level of significance a $=0.05$, between the views of both genders of infants and preschool of our sample for the Frecognition factor $(F=0.015, p=0,902>a=0.05)$, the Fusage factor $(F=0.015, p=0.902>a$ $=0.05)$, Fwhat a PC is Factor $(\mathrm{F}=0.011, \mathrm{p}=0.915>\mathrm{a}=0.05)$ and Fif continues to be $\mathrm{a} P \mathrm{C}$ factor $(\mathrm{F}=0.306, \mathrm{p}=0.582>\mathrm{a}=0.05)$.

Table 1: Children's Opinion according to gender

\begin{tabular}{|l|l|l|l|l|}
\hline & Gender & Means* & SD & $\mathrm{n}$ \\
\hline \multirow{4}{*}{ Frecognition } & GIRLS & $53.09 \mathrm{a}$ & 26.182 & 47 \\
\cline { 2 - 5 } & BOYS & $53.70 \mathrm{a}$ & 23.644 & 53 \\
\cline { 2 - 5 } & Total & 53.412 & 24.744 & 100 \\
\hline \multirow{3}{*}{ Fusage } & GIRLS & $104.21 \mathrm{a}$ & 52.768 & 47 \\
\cline { 2 - 5 } & BOYS & $105.45 \mathrm{a}$ & 47.564 & 53 \\
\cline { 2 - 5 } & Total & 104.87 & 49.824 & 100 \\
\hline & GIRLS & $42.55 \mathrm{a}$ & 27.566 & 47 \\
\hline
\end{tabular}




\section{$\triangle$ Macrothink}

International Journal of Learning \& Development

ISSN 2164-4063

2012, Vol. 2, No. 3

\begin{tabular}{|l|l|l|l|l|}
\hline \hline \multirow{2}{*}{ Fwhat a PC is } & BOYS & $43.11 \mathrm{a}$ & 24.974 & 53 \\
\cline { 2 - 5 } & Total & 42.85 & 26.091 & 100 \\
\hline \multirow{3}{*}{$\begin{array}{l}\text { Fcontinues to be a } \\
\text { PC }\end{array}$} & GIRLS & $1.91 \mathrm{a}$ & 0.282 & 47 \\
\cline { 2 - 5 } & BOYS & $1.94 \mathrm{a}$ & 0.233 & 53 \\
\cline { 2 - 5 } & Total & 1.93 & 0.256 & 100 \\
\hline
\end{tabular}

*For each factor means that are not followed by a letter differ statistically significant in the level of significance a $=0.05$ according to ANOVA's results.

Differences between infants and preschoolers according to the identification and usage of the computer, what actually the computer is and finally if the computer's external appearance was different would it still be a computer

Analysis showed there was a statistically significant difference on the level of significance a $=0.05$, between the views of infants and preschool for the Frecognition factor $(\mathrm{F}=24.254, \mathrm{p}$ $=0.000<\mathrm{a}=0.05)$, Fusage factor $(\mathrm{F}=24.254, \mathrm{p}=0.000<\mathrm{a}=0.05)$, Fwhat a PC is factor $(\mathrm{F}=$ $29.318, \mathrm{p}=0.000<\mathrm{a}=0.05)$ and Fif continues to be a $\mathrm{PC}$ factor $(\mathrm{F}=6.431, \mathrm{p}=0.013<\mathrm{a}$ $=0.05)$.

Table 2: Children's Opinion according to age

\begin{tabular}{|l|l|l|l|l|}
\hline & Age & Means* & SD & $\mathrm{n}$ \\
\hline \multirow{4}{*}{ Frecognition } & PRESCHOOL & $43.49 \mathrm{a}$ & 21.920 & 55 \\
\cline { 2 - 5 } & INFANTS & $65.53 \mathrm{~b}$ & 22.685 & 45 \\
\cline { 2 - 5 } & Total & 53.41 & 24.744 & 100 \\
\hline \multirow{4}{*}{ Fusage } & PRESCHOOL & $84.71 \mathrm{a}$ & 43.995 & 55 \\
\cline { 2 - 5 } & INFANTS & $129.51 \mathrm{~b}$ & 45.619 & 45 \\
\cline { 2 - 5 } & Total & 100.87 & 49.824 & 100 \\
\hline \multirow{5}{*}{$\begin{array}{l}\text { Fcontinues to be PC is } \\
\text { a PC }\end{array}$} & PRESCHOOL & $31.58 \mathrm{a}$ & 22.871 & 55 \\
\cline { 2 - 5 } & INFANTS & $56.62 \mathrm{~b}$ & 23.174 & 45 \\
\cline { 2 - 5 } & Total & 42.85 & 26.091 & 100 \\
\cline { 2 - 5 } & INESCHOOL & $1.87 \mathrm{a}$ & 0.336 & 55 \\
\cline { 2 - 5 } & Total & $2.00 \mathrm{~b}$ & 0.000 & 45 \\
\hline \multirow{2}{*}{} & 1.93 & 0.256 & 100 \\
\hline
\end{tabular}

*For each factor means that are not followed by a letter differ statistically

significant in the level of significance a $=0.05$ according to ANOVA's results.

Differences between children from Florina and Thessaloniki according to the recognition and usage of computer, what actually the computer is and finally if the computer's external appearance was different would it still be a computer.

The analysis showed that there was no statistically significant difference on the level of significance $\mathrm{a}=0.05$, between the views of children from Florina and Thessaloniki concerning the Frecognition factor $(F=0.002, p=0.962>a=0.05)$, Fusage factor $(F=0.001$, $\mathrm{p}=0.977>\mathrm{a}=0.05)$, Fwhat a PC is factor $(\mathrm{F}=0.005, \mathrm{p}=0.942>\mathrm{a}=0.05)$ and Fif continues to be a $\mathrm{PC}$ factor $(\mathrm{F}=0.005, \mathrm{p}=0.942>\mathrm{a}=0.05)$.

Table 3: Children's Opinion according to place of residence

\begin{tabular}{|l|l|l|l|l|}
\hline & Place of residence & Means* & SD & $\mathrm{n}$ \\
\hline \multirow{3}{*}{ Frecognition } & FLORINA & $53.99 \mathrm{a}$ & 23.333 & 67 \\
\cline { 2 - 5 } & THESSALONIKI & $53.23 \mathrm{a}$ & 27.382 & 33 \\
\hline
\end{tabular}




\begin{tabular}{|c|c|c|c|c|}
\hline & Total & 53.41 & 24.744 & 100 \\
\hline \multirow{3}{*}{ Fusage } & FLORINA & $104.97 \mathrm{a}$ & 47.477 & 67 \\
\hline & THESSALONIKI & $104.67 \mathrm{a}$ & 55.055 & 33 \\
\hline & Total & 104.87 & 49.824 & 100 \\
\hline \multirow{3}{*}{ Fwhat a $\mathrm{PC}$ is } & FLORINA & $42.72 \mathrm{a}$ & 28.448 & 67 \\
\hline & THESSALONIKI & $43.12 \mathrm{a}$ & 23.174 & 33 \\
\hline & Total & 42.85 & 26.091 & 100 \\
\hline \multirow{3}{*}{$\begin{array}{l}\text { Fcontinues to } \\
\text { be a PC }\end{array}$} & FLORINA & $42.72 \mathrm{a}$ & 25.073 & 67 \\
\hline & THESSALONIKI & $43.12 \mathrm{a}$ & 28.448 & 33 \\
\hline & Total & 42.85 & 26.091 & 100 \\
\hline
\end{tabular}

*For each factor mean that are not followed by a letter differ statistically significant in the level of significance $a=0.05$ according to ANOVA's results.

Differences between children who had or had not a PC in the kindergarten according to the recognition and usage of computer, what the computer actually is and finally if the computer's external appearance was different would it still be a computer

Analysis showed statistically significant differences on the level of significance $a=0.05$, as to the existence of computer in kindergarten to Frecognition factor $(\mathrm{F}=6.813$, $\mathrm{p}=0.01<\mathrm{a}=0.05)$ and Fusage factor $(\mathrm{F}=7.025, \mathrm{p}=0.09<\mathrm{a}=0.05)$. Analysis showed that there was no statistically significant differences in the level of significance $a=0.05$, as to the existence of computer in kindergarten for the Fwhat a $P C$ is factor $(F=8.372, p=0.06>$ $\mathrm{a}=0.05)$ and to Fif continues to be a PC factor $(\mathrm{F}=2.126, \mathrm{p}=0.148>\mathrm{a}=0.05)$.

Table 4: Children's Opinion according to existence of a computer in the kindergarten

\begin{tabular}{|l|l|l|l|l|}
\hline & Computer's Existence & Means* & SD & $\mathrm{n}$ \\
\hline \multirow{4}{*}{ Frecognition } & NO & $41.59 \mathrm{a}$ & 17.797 & 22 \\
\cline { 2 - 5 } & YES & $56.74 \mathrm{~b}$ & 25.488 & 78 \\
\cline { 2 - 5 } & Total & 53.41 & 24.744 & 100 \\
\hline \multirow{4}{*}{ Fusage } & NO & $80.73 \mathrm{a}$ & 35.876 & 22 \\
\cline { 2 - 5 } & YES & $111.68 \mathrm{~b}$ & 51.257 & 78 \\
\cline { 2 - 5 } & Total & 104.87 & 49.824 & 100 \\
\hline \multirow{4}{*}{ Fwhat a PC is } & NO & $29.14 \mathrm{a}$ & 18.944 & 22 \\
\cline { 2 - 5 } & YES & $46.78 \mathrm{~b}$ & 26.617 & 78 \\
\cline { 2 - 5 } Fe a PC & Total & 42.85 & 26.091 & 100 \\
\cline { 2 - 5 } & NO & $2.00 \mathrm{a}$ & 0.000 & 22 \\
\cline { 2 - 5 } & YES & $1.91 \mathrm{~b}$ & 0.288 & 78 \\
\cline { 2 - 5 } & Total & 1.93 & 0.250 & 100 \\
\hline \multirow{2}{*}{} & & & & \\
\hline
\end{tabular}

* For each factor means that are not followed by a letter differ statistically significant in the level of significance a $=0.05$ according to ANOVA's results.

Differences related to father's occupation according to the recognition and usage of computer, what the computer actually is and finally if the computer's external appearance was different would it still be a computer

Multivariate Analysis of Variance showed the there was no statistically significant difference on the level of significance $a=0.05$, as to father's occupation and for all four factors, 


\section{Macrothink MInstitute}

Frecognition $(\mathrm{F}=2.311, \mathrm{p}=0.105>\alpha=0.05)$, Fusage $(\mathrm{F}=2.379, \mathrm{p}=0.09>\alpha=0.05)$, Fwhat a $\mathrm{PC}$ is, $(\mathrm{F}=2.896, \mathrm{p}=0.06>\alpha=0.05)$, and Fif continues to be a $\mathrm{PC} \quad(\mathrm{F}=0.817, \mathrm{p}=0.445>\alpha=0.05)$.

Table 5: Children's Opinion according to father's occupation

\begin{tabular}{|c|c|c|c|c|}
\hline & Father's occupation & Means* & SD & $\mathrm{n}$ \\
\hline \multirow{4}{*}{ Frecognition } & 1 & $48.37 \mathrm{a}$ & 24.534 & 46 \\
\hline & 2 & $55.36 \mathrm{a}$ & 24.166 & 36 \\
\hline & 3 & $62.39 \mathrm{a}$ & 24.651 & 18 \\
\hline & Total & 53.41 & 24.744 & 100 \\
\hline \multirow{4}{*}{ Fusage } & 1 & $92.61 \mathrm{a}$ & 49.340 & 46 \\
\hline & 2 & $108.78 \mathrm{a}$ & 48.717 & 36 \\
\hline & 3 & $123.28 \mathrm{a}$ & 49.501 & 18 \\
\hline & Total & 104.87 & 49.824 & 100 \\
\hline \multirow{4}{*}{ Fwhat a $\mathrm{PC}$ is } & 1 & $36.96 \mathrm{a}$ & 25.759 & 46 \\
\hline & 2 & $45.08 \mathrm{a}$ & 25.545 & 36 \\
\hline & 3 & $53.44 \mathrm{a}$ & 25.320 & 18 \\
\hline & Total & 42.85 & 26.091 & 100 \\
\hline \multirow{4}{*}{$\begin{array}{l}\text { Fcontinues to } \\
\text { be a PC }\end{array}$} & 1 & $1.91 \mathrm{a}$ & 0.285 & 46 \\
\hline & 2 & $1.92 \mathrm{a}$ & 0.280 & 36 \\
\hline & 3 & $2.00 \mathrm{a}$ & 0.000 & 18 \\
\hline & Total & 1.93 & 0.256 & 100 \\
\hline
\end{tabular}

*For each factor means that are not followed by a letter differ statistically significant in the level of significance a $=0.05$ according to the results of Tukey's HSD test.

Differences related to mother's occupation according to the recognition and usage of computer, what the computer actually is and finally if the computer's external appearance was different would it still be a computer

Analysis showed that there was a statistically significant difference on the level of significance $\alpha=0.05$, between the children according to mother's occupation in all four Factors. More specifically, there were statistically significant differences to factors Frecognition $(\mathrm{F}=3.121$, $p=0.03<\alpha=0.05)$, Fusage $(F=3.142, p=0.029<\alpha=0.05)$, Fwhat a $P C$ is $(F=3.412, p=0.021$ $<\alpha=0.05)$ and Fif continues to be a PC.

Table 6: Children's Opinion according to Mother's occupation

\begin{tabular}{|l|l|l|l|l|}
\hline & Mother's occupation & Means* & SD & $\mathrm{n}$ \\
\hline \multirow{5}{*}{ Frecognition } & 1 & $42.07 \mathrm{a}$ & 18.002 & 15 \\
\cline { 2 - 5 } & 2 & $52.80 \mathrm{a}$ & 24.397 & 30 \\
\cline { 2 - 5 } & 3 & $79.40 \mathrm{~b}$ & 15.502 & 5 \\
\cline { 2 - 5 } Fusage & 4 & $54.58 \mathrm{a}$ & 25.741 & 50 \\
\cline { 2 - 5 } & Total & 53.41 & 24.744 & 100 \\
\cline { 2 - 5 } & 1 & $81.87 \mathrm{a}$ & 36.441 & 15 \\
\cline { 2 - 5 } & 2 & $103.60 \mathrm{a}$ & 49.099 & 30 \\
\cline { 2 - 5 } & 3 & $157.20 \mathrm{~b}$ & 30.886 & 5 \\
\cline { 2 - 5 } & 4 & $107.30 \mathrm{a}$ & 51.800 & 50 \\
\cline { 2 - 5 } & Total & 104.87 & 49.824 & 100 \\
\hline
\end{tabular}




\begin{tabular}{|l|l|l|l|l|}
\hline \hline \multirow{5}{*}{ Fwhat a PC is } & 1 & $29.667 \mathrm{a}$ & 6.503 & 15 \\
\cline { 2 - 5 } & 2 & $42.167 \mathrm{a}$ & 4.598 & 30 \\
\cline { 2 - 5 } & 3 & $70.200 \mathrm{~b}$ & 11.264 & 5 \\
\cline { 2 - 5 } & 4 & $44.480 \mathrm{a}$ & 3.562 & 50 \\
\cline { 2 - 5 } & Total & 42.85 & 26.091 & 100 \\
\hline \multirow{3}{*}{$\begin{array}{l}\text { Fcontinues a PC } \\
\text { be }\end{array}$} & 1 & $1.73 \mathrm{a}$ & 0.458 & 15 \\
\cline { 2 - 5 } & 2 & $1.97 \mathrm{~b}$ & 0.183 & 30 \\
\cline { 2 - 5 } & 3 & $2.00 \mathrm{a}$ & 0.000 & 5 \\
\cline { 2 - 6 } & 4 & $1.96 \mathrm{ab}$ & 0.198 & 50 \\
\cline { 2 - 5 } & Total & 1.93 & 0.256 & 100 \\
\hline
\end{tabular}

*For each factor means that are not followed by a letter differ statistically significant in the level of significance a $=0.05$ according to Tukey's HSD test results.

Differences related to father's educational level according to the recognition and usage of computer, what actually the computer is and finally if the computer's external appearance was altered would it still be computer.

Analysis of Variance showed there are was no statistically significant differences on the level of significance $\alpha=0,05$, according to father's educational level for all four factors, Frecognition $(F=1.891, p=0.156>\alpha=0.05)$, Fusage $(F=1.936, p=0.150>\alpha=0,05)$, Fwhat a $P C$ is $(F=2.185$, $p=0.118>\alpha=0,05)$ and Fif continues to be a PC $(F=0.708, p=0.495>\alpha=0.05)$.

Table 7: Children's Opinion according to Father's educational level

\begin{tabular}{|c|c|c|c|c|}
\hline & $\begin{array}{l}\text { Father's educational } \\
\text { level }\end{array}$ & Means* & SD & $\mathrm{n}$ \\
\hline \multirow{4}{*}{ Frecognition } & 1 & $64.19 \mathrm{a}$ & 24.628 & 16 \\
\hline & 2 & $52.68 \mathrm{a}$ & 22.889 & 25 \\
\hline & 3 & $50.80 \mathrm{a}$ & 25.144 & 59 \\
\hline & Total & 53.41 & 24.744 & 100 \\
\hline \multirow{4}{*}{ Fusage } & 1 & $126.81 \mathrm{a}$ & 49.526 & 16 \\
\hline & 2 & $103.40 \mathrm{a}$ & 46.196 & 25 \\
\hline & 3 & $99.54 \mathrm{a}$ & 50.570 & 59 \\
\hline & Total & 104.87 & 49.824 & 100 \\
\hline \multirow{4}{*}{ Fwhat a $\mathrm{PC}$ is } & 1 & $55.00 \mathrm{a}$ & 25.495 & 16 \\
\hline & 2 & $42.16 \mathrm{a}$ & 24.513 & 25 \\
\hline & 3 & $39.85 \mathrm{a}$ & 26.365 & 59 \\
\hline & Total & 42.85 & 26.091 & 100 \\
\hline \multirow{4}{*}{$\begin{array}{l}\text { Fcontinues to } \\
\text { be a PC }\end{array}$} & 1 & $2.00 \mathrm{a}$ & 0.000 & 16 \\
\hline & 2 & $1.92 \mathrm{a}$ & 0.277 & 25 \\
\hline & 3 & $1.92 \mathrm{a}$ & 0.281 & 59 \\
\hline & Total & 1.93 & 0.256 & 100 \\
\hline
\end{tabular}

*For each factor means that are not followed by a letter differ statistically

significant in the level of significance $\mathrm{a}=0.05$ according to Tukey's HSD test results. 


\section{Mll Macrothink}

International Journal of Learning \& Development

ISSN 2164-4063

2012, Vol. 2, No. 3

Differences related to mother's educational level according to the recognition and usage of computer, what the computer actually is and finally if the computer's external appearance was different would it still be a computer

Analysis of Variance showed there was no statistically significant differences on the level of significance $\alpha=0,05$, according to mother's educational level for 3 factors, Frecognition( $F=5.597, p=0.005<\alpha=0.05)$, Fusage $(F=5.688, p=0.005<\alpha=0,05)$, Fwhat a $P C$ is $(F=6.577, p=0.002<\alpha=0,05)$, except for Fif continues to be a PC factor $(F=1.988, p=0.143$ $>\alpha=0.05)$.

Table 8: Children's Opinion according to Mother's educational level

\begin{tabular}{|c|c|c|c|c|}
\hline & $\begin{array}{l}\text { Mother's educational } \\
\text { level }\end{array}$ & Means* & SD & $\mathrm{n}$ \\
\hline \multirow{4}{*}{ Frecognition } & 1 & $57.74 \mathrm{a}$ & 24.313 & 23 \\
\hline & 2 & $60.84 \mathrm{ab}$ & 23.407 & 38 \\
\hline & 3 & $43.82 \mathrm{ac}$ & 23.546 & 39 \\
\hline & Total & 53.41 & 24.744 & 100 \\
\hline \multirow{4}{*}{ Fusage } & 1 & $113.07 \mathrm{a}$ & 48.895 & 23 \\
\hline & 2 & $119.92 \mathrm{ab}$ & 47.148 & 38 \\
\hline & 3 & $85.00 \mathrm{ac}$ & 47.330 & 39 \\
\hline & Total & 104.87 & 49.824 & 100 \\
\hline \multirow{4}{*}{ Fwhat a $\mathrm{PC}$ is } & 1 & $48.13 \mathrm{a}$ & 25.133 & 23 \\
\hline & 2 & $51.08 \mathrm{ab}$ & 24.675 & 38 \\
\hline & 3 & $31.72 \mathrm{c}$ & 24.560 & 39 \\
\hline & Total & 42.85 & 26.091 & 100 \\
\hline \multirow{4}{*}{$\begin{array}{l}\text { Fcontinues to be a } \\
\text { PC }\end{array}$} & 1 & $2.00 \mathrm{a}$ & 0.000 & 23 \\
\hline & 2 & $1.95 \mathrm{a}$ & 0.226 & 38 \\
\hline & 3 & $1.95 \mathrm{a}$ & 0.339 & 39 \\
\hline & Total & 1.93 & 0.256 & 100 \\
\hline
\end{tabular}

*For each factor means that are not followed by a letter differ statistically significant in the level of significance $a=0.05$ according to Tukey's HSD the results.

\section{Discussion}

This study was an attempt to explore the infant's and preschool children's perception in Greece for the PC and its components. It was found that the biggest percentage of preschool children and a large percentage of infants, based their opinions on the physical characteristics of artificial objects primarily to the shape, color and size (e.g. the computer is a box) and did not measured some essential internal characteristics, a fact that comes in agreement with the theory of similarity (Smith \& Medin, 1981; Medin, 1989). However, a satisfactory description of concepts requires the interpretation of the relation between the characteristics of objects and not just the enumeration of a list of features (Ziori, 2005). In contrast to the theories that are based on the similarity, the cognitive theoretical view includes people's knowledge and theories for the world (Maridaki-Kassotaki, 2002; Rips, 1989). In particular, theories provide information about what the important features are, what their function is, the causal and explanatory relation between them, as well as the relations between concepts. Therefore, 
learning a new category depends a lot on previous knowledge about other related categories (Medin \& Ortony, 1989). When, for example an infant sees for first time a photo of a printer, probably uses its general knowledge about the computers. In our study, the phenomenon of metaphor or parallelism of the computer or its components with other objects was observed (e.g. "the screen is like a television" or "it is a television", "the central unit and the printer are machines", etc.) mainly on behalf of infants. It seems that infants, compared to preschoolers, uses the essential characteristics more in order to determine the concept of the computer and its components (recognition-usage-maintenance of its identity), (see Table 2). Keil (1989), supports that children's first perceptions about the world are "simplistic" and form the basis of their initial theoretical and cognitive knowledge systems. With the accumulation of knowledge and experience these theoretical systems are broadened and allow the formation of new assumptions for the determination of the attributes that define the real content of a concept. Infants begin to widen and redefine the actual content of the computer's concept. That is why they give more accurate answers compared to the preschoolers.

The majority of the children had obvious difficulties to delimit the concept of the PC and also to cognize what it is and what its function is. This difficulty was expected because the computer is an artifact with complex functions, that are essentially based on its internal characteristics. In parallel, the children's perceptions for the computer and its components depend on factors such as the occupation and education level of the mother and also the existence of a PC in the kindergarten. In contrast, the children's gender, the place of residence, the occupation and the educational level of the father does not seem to have a significant impact.

In particular, the mother's occupation considerably affects the children's performance. It was found that children with a mother that was self-employed - scientist or civil servant, had a statistically significant greater number of correct answers, in comparison to the children with their mother being a farmer or worker and from children with their mothers being a private employee, self employed or trader (see Table 6). The mother's educational level seems to affect children's perception, although something intriguing happens: the highest number score of correct answers was found in children whose mothers graduated from secondary education. This finding may be explained by the high expectations that these mothers had for their children's education. Although, they did not graduate from college, they desire something like that for their children. The lowest scores were found in children whose mothers only graduated from primary education. It is surprising that as for the question concerning the alteration or not of the computer's identity, no differences were appeared between the 3 teams, a fact that needs further exploration (see Table 8).

Although the father's occupation does not seem to distinguish statistically significant children's answers, it is likely that children with a freelancer-scientist or civil servant father had highest number of correct answers, in comparison to children whose father was a farmer or worker and also from children whose father was a private employee, freelancer-technician or trader (see Table 5). A similar trend also appears due to the father's educational level, where the most correct answers given where from children whose father had a higher education 
degree (see Table 7). Statistical significance finding related with mother's occupation and educational level may reflects mother's highest involvement in children's education in Greek family. Similar correlations have been found in children's school performance and success in their admission to a University school (Kyridis, Mavrikaki, \& Neroutsos, 1995; Kyridis, 1997; Kyridis \& Dew, 2001).

Additionally, the present findings comes in agreement with those of international studies (Avand \& Krosnick, 2005; Becker, 2000; Primavera et al., 2001), that emphasize the important role that parent's education and occupation play in teaching their children new technologies. As Colvert and her collaborators (2005) remarked, the technological illiteracy is intense to infants with lower educational and socio-economic family level. Parents with high educational level have a more positive attitude due to the computer, while often tend to reinforce their child to interact with it (Vecker, 2000).

The existence of a computer in the kindergarten seems to positive contribute to the perception of preschool children for it (see Table 4). Children that come in touch with the computer in the kindergarten give more accurate answers. What's impressive is the absence of statistically significant differences in the question what the computer is and whether its identity changes or not with the alteration of its external characteristics, between the two groups. This may be due to the fact that the existence of computer in the kindergarten does not automatically implies that children are taught the PC's components (I teach PC). Computer is mostly used in a way to teach other cognitive subjects (I teach through the PC). As Clements (1994) remarks, the kindergarteners who have a computer in their classroom use it in a limited extent, mainly to teach basic skills. Usually because there is only one, children have very few opportunities to come into substantial interaction with it. The frequent, seamless and equitable usage of computer from all children and kindergartener's education to new technologies can significantly contribute to its learning (Haugland, 1999).

As for the gender factor, it was found that there were no statistically significant differences between girls and boys answers to the conceptual definition of computer and its identity, as well as the recognition and usage of its parts and components (see Table 1). Data of the current study come in agreement with the latest international findings (Calvertetal, 2005; Subramanyam et al., 2001). Newburger (2001), based on data of the Statistical Commition of the U.S., concluded that there are not any differences in the usage of computers between boys and girls in the age of 3-17 (except the games section where boys seems to spent more time). Other researchers (Essa, 1987; Lepper, 1985), allege that the changes in computer usage between the two genders appear in a later time.

Place of children's residence did not seem to significantly influence the perceptions about the function and usage of computer (see Table 3). The small number of sample and the comparison of rural/suburban and urban areas (and not exclusively rural compared with urban), may not reflect the real differences of lifestyle and standard of living between residents of different areas.

Knowledge is a form of participation in social events, a process of life. It is acquired through social interactions in which everyone takes part and incorporates into the cultural capital that every person has. Specifically, social cognition is the product of a long process of interaction with the environment in which the partakers of all 
ages socialize and acquire knowledge and skills. They involve in a social learning process. And the effectiveness of this process depends a lot on the quality and type of stimuli that is provided by the environment. At this level, the cultural capital theory of Bourdieu \& Passeron (1964 \& 1970), as well as the linguistic codes theory of Bernstein's (1971), consists an explanation model of educational inequality, which the correlation between the products of social learning was based, especially those related to the family environment of children and school success. Today, children and adults are exposed to a tremendous amount of information and stimuli. Social learning process is of particular importance, especially to the direction of the potential transformation of social knowledge to typical. School as a social institution, the only one who is typically responsible for the transmission, reproduction and certification of knowledge, has to decide which knowledge should be typical. For example, in previous years computers were used as a technology product of limited usage which required special

knowledge that every user acquired mainly outside the formal educational system. Today, former social knowledge is mostly typical since computers are widely used in schools as a subject and tool of learning/teaching. Knowledge and perceptions that children might have about computers gained outside the school depends, according to this study, mainly on social variables that are identified by the environment -mostly the family- in which children grow up. School is asked to provide formal knowledge about computers to children who have different cognitive and cultural capital.

Therefore, recognizing the catalytic role of sociocultural environment and experiences of infant's perceptions about the computer, education system needs to provide same opportunities in all children in order to acquire as many experiences and knowledge about new technologies, reducing in that way the educational inequality (Primavera et al., 2001). After all, many researchers (Haugland, 1992 \& 1999; Nastasi \& Clements, 1994), believe that computer helps promote the mathematical thinking of children, acquisition of reading, and evolvement of creativity. Computer is an artifact that has dynamically entered in our lives and today's kindergarten should not remain isolated from society and evolution of our ages in general. "Tomorrow's" kindergarten has to provide opportunities to infants for familiarization, active interaction with the computer and dynamic cooperation with the other children, together with promotion of emotional and cognitive development (Elkind, 1985; Haugland \& Wright, 1997). 


\section{References}

Australian Bureau of Statistics (2000). Household use of information technology, Australia. Canberra: Commonwealth of Australia.

Avand, S., \& Krosnick, J. (2005). Demographic predictors of media use among infants, toddlers and preschoolers. American Behavioral Scientist, 48, 539-561.

Babbie, E. \& Halley, F. (1998). Adventures in Social Research. Data Analysis Using SPSS for Windows 95 . Thousand Oakes: Pine Forge Press.

Bandura, A. (1986). Social foundations of thought and action. A social cognitive theory . N. Yersey: Prentice-Hall.

Bandura, A. (1989). Human agency in social cognitive theory. American Psychologist, 44, 1175-1184.

Becker, H.J. (2000). Who's wired and who's not: Children's access to and use of computer technology. In Becker (Ed.), The future of children: Children and computer technology, pp. 44-75. Los Altos: The David and Lucile Packard Foundation.

Bernstein, B. (1971). Class, codes and control. London: Routledge \& Kegan Paul.

Bhargava, A., Kirova-Petrova, \& McNair, S. (1999). Computers, gender bias and young children. Information Technology in Childhood Education, 4, 263-274.

Bourdieu, P. \& Passeron, J.C. (1964). Les heritiers: Les e tudiants et la culture. Paris: Minuit. Bourdieu, P. \& Passeron, J.C. (1970). La reproduction. Ele ments pour une the orie du systeme d'enseignement . Paris: Minuit.

Bradshaw, J., Clegg, S., \& Trayhurn, D. (1995). An investigation into gender bias in educational software used in Einglish primary schools. Gender and Education, 7(2), 167-174. Bryman, A. \& Cramer, D. (1999). Quantitative Data Analysis with SPSS Release 8 for Windows: A Guide for Social Scientists . London and New York: Routledge.

Calvert, S., Rideout, V., Woolard, J., Barr, R., \& Strouse, G. (2005). Age, ethnicity, and socioeconomic patterns in early computer use. American Behavioral Scientist, 48, 590-607.

Carey, S. (1985). Conceptual change in childhood. Cambridge, MA: Cambridge University Press.

Clements, D. H. (1994). The uniqueness of the computer as a learning tool: Insights from reserch and practice. In J.L. Wright \& D.D. Shade (Eds.), Young children: Active learners in a technological age, pp. 154-168. Washington, DC: NAEYC.

Clements, D.H. (1987). Computers and young children: A review of the research. Young Children, 43, 34-44.

Clemments, D.H. (1998). Young children and technology. (ERIC Document Reproduction Service No. ED 416 991).

Coakes, S., \& Steed, L. (1999). SPSS Analysis without Anguish. Singapore: John Willey \& Sons.

Derman-Sparks, L. (1989). Anti-Bias Curriculum: Tools for empowering young children. Washington, DC: NAEYC.

Elkind, D. (1985). The impact of computer use on cognitive development in young children: A theoretical analysis. Computers in Human Behavior, 1, 131-141.

Essa, E. (1987). The effects of a computer on preschool children's activities. Early Childhood Research Quarterly, 2, 377-382. 
Gelman, S.A., \& Markman, E.M. (1986). Categories and induction in young children. Cognition, 23, 183-208.

Gelman, S.A., \& Markman, E.M. (1987). Young children's inductions from natural kinds: The role of categories and appearances. Child Development, 58, 1532-1554.

Gelman, S.A., \& Wellman, H.M. (1991). Insides and essences: Early understanding of the non-obvious. Cognition, 38, 213-244.

Hair, J., Anderson, R., Tatham, R. and Black, W. (1995). Multivariate Data Analysis With Raedings . USA: Prentice-Hall International, Inc.

Haugland, S. (1992). The effect on computer software on preschool children's developmental gains. Journal of Computing in Childhood Education, 3, 15-30.

Haugland, S. (1999). What role should technology play in young children's learning? Young Children, 54, 26-31.

Haugland, S., \& Wright, J. (1997). Young children and technology: A world of discovery. New York: Allyn \& Bacon.

Keil F.C. (1994). The birth and nurturance of concepts by domains: The origins of concepts of living things. N.Y.: Cambridge University Press.

Keil, F.C. (1989). Concepts, kinds, and cognitive development. Cambridge, MA: MIT Press.

Keil, F.C., \& Batterman, N. (1984). A characteristic - to- defining shift in the development of word meaning. Journal of Verbal Learning and Verbal Behavior, 23, 221-236.

Kinnear, P. \& Gray, C. (1995). SPSS for Windows Made Simple. East Sussex: Psychology Press Ltd.

Kirk, R. (1995). Experimental Design: Procedures for the Behavioral Sciences. Pacific Grove, CA: Brooks/Cole Publishing Company, ITP.

Klockars A., and Sax, G., (1986). Multiple Comparisons. Sage University Paper series on Quantitative Applications in the Social Sciences, 07-061. Newbury Park, CA: Sage.

Koch, M. (1994). No girls allowed! Technos, 3(3), 14-19. Kominski, R. \& Newberger, E. (1999, August). Access denied: Changes in computer ownership and use: 1987-1997. Paper presented at the annual meeting of the American Sociological Association, Chicago, IL.

Kuehl, R. (2000). Designs of Experiments: Statistical Principles of Research Design and Analysis. Pacific Grove: Duxbury Thomson Learning.

Kyridis, A. \& Drosos, E. (2001). Thirty years of inequality in Greek Education. Contemporary Education, 118, 68-79.

Kyridis, A. (1997). The Greek educational inequality and the access to the University (1955 -1985). Athens: Gutenberg.

Kyridis, A., Mavrikaki, E. \& Neroutsos, A. (1995). Contribution to the study of Greek educational inequality based on the statistics of higher education, 1984-1991. Contemporary Education, 76, 29-37.

Lepper, M. (1985). Microcomputers in education: Motivational and social issues. American Psychologist, 40, 1-18.

Maridaki-Kassotaki, A. (2002). The formulation of specific concepts: Psychological approach. Athens: Grigoris.

Medin, D.L. (1989). Concepts and conceptual structure. American Psychologist, 44, 1469-1481. 
Medin, D.L., \& Ortony, A. (1989). Psychological essentialism. In S. Vosniadou \& A. Ortony, (Eds.), Similarity and analogical reasoning, pp. 179-195. Cambridge: Cambridge University Press.

Mendenhall, W. \& Sincich, T. (1996). A Second Course in Statistics: Regression Analysis. New Jersey: Prentice Hall, Inc.

Ministry of Education and Religious Affairs (2004). Information Society. Ahtens. Retrieved in 17/5/2012 from www.ypepth.gr

Nastasi, B., \& Clements, D.H. (1994). Effectance motivation, perceived scholastic competence, and higher-order thinking in two cooperative computer environments. Journal of Educational Computing Research, 10, 249-275.

Nelson, C. \& Watson, A. (1991). The computer gender gap: Children's attitudes, performance and socialization. Journal of Educational Technology Systems, 19(4), 243-353.

Newburger, E.C. (2001). Home computers and Internet use in the United States: August 2000. Washington, DC: U.S. Department of Commerce, Economics and Statistics Administration, U.S. Bureau of the Census.

Primavera, J., Wiederlight, P., \& DiGiacomo, T. (2001, August). Technology access for low-income preschoolers: Bridging the digital divide. Paper presented at the annual meeting of the American Psychological Association, San Francisco, CA.

Rips, L.J. (1989). Similarity, typicality, and categorization. In S. Vosniadou \& A. Ortony, (Eds.), Similarity and analogical reasoning, pp. 21-59. Cambridge: Cambridge University Press.

Sharma, S. (1996). Applied Multivariate Techniques. USA: John Willey \& Sons, Inc.

Shashaani, L. (1994). Gender differences in computer experience and ts influence on computer attitudes. Journal of Educational Computing Research, 11(4), 347-367.

Smith, J.D., \& Medin, DL. (1981). Categories and concepts. Cambridge, MA: Harvard University Press.

Spriegler, D. \& Keil, F.C. (1991). Early differentiation of causal mechanisms appropriate to biological \& non-biological kinds. Child Development, 12, 767-781.

Subramanyam, K. Kraut, R., Greenfield, P., \& Gross, E. (2001). New forms of electronic media. In D. Singer \& J. Singer (Eds.), Handbook of children and the media, pp. 73-99. Thousand Oaks, CA: Sage.

Toothacker, Larry E. (1993). Multiple comparisons procedures. Thousand Oaks, CA: Sage Publications. Quantitative Applications in the Social Sciences series No 89.

US. Department of Commerce (1997). Falling through the net II: New data on the digital divide. Washington, DC: U.S. Department of Commerce.

Vosniadou, S. (1992). Conceptual change in children. In S. Vosniadou (Ed), Texts of developmental psychology, Vol. II: Thought] (pp. 149-164). Athens: Gutenberg.

Vosniadou, S. (2001). Introduction to Psychology, Vol. I: Biological, developmental and behavioral approaches, Cognitive Psychology. Athens: Gutenberg.

Williams, S.W., \& Oqletree, S.M. (1992). Preschool children's computer interest and competence effects of sex and gender role. Early Childhood Research Quarterly, 7, 135-143. Ziori, E. (2005). Theories of the formation of specific concepts. Psychology, 12(2), 179-194. 